\title{
Utilization of Dairy Effluent for Food Grade Protease Production Using Bacillus sp.
}

\section{P. C. Madhu}

Department of Biotechnology, MET'S School of Engineering, Kuruvilassery, Mala, Kerala, India

Email address:

madhupc2014@gmail.com

\section{To cite this article:}

P. C. Madhu. Utilization of Dairy Effluent for Food Grade Protease Production Using Bacillus sp. American Journal of Bioscience and Bioengineering. Vol. 4, No. 6, 2016, pp. 90-95. doi: 10.11648/j.bio.20160406.15

Received: August 29, 2016; Accepted: December 30, 2016; Published: January 24, 2017

\begin{abstract}
Food grade proteases are proteyolytic enzymes having application in baking, food processing, protein modification etc. As a commodity product, pressure on protease market is on prize reduction and increasing performance. Hence our objective was to isolate a potent protease-producing microorganism and formulate a cost effective medium for neutral protease synthesis by the potent microbial culture. In order to achieve the objective, a proteolytic bacterium was isolated from soil using milk agar medium and the bacteria was identified as Bacillus sp. by morphological and biochemical characterization. Dairy industry effluent was then studied as a medium for neutral protease synthesis by the potent bacteria. Supplementation of mineral salt to the medium did not show profound influence of environmental factors such as medium $\mathrm{pH}$, incubation temperature, agitation rate and incubation time on enzyme production. Optimum enzyme titers were found at $\mathrm{pH} 7$ when incubated at $37^{\circ} \mathrm{C}$ and $120 \mathrm{rpm} 48 \mathrm{~h}$. Dairy industry effluent was thus found to be a cost effective medium for neutral protease synthesis by Bacillus sp.
\end{abstract}

Keywords: Dairy Industry, Dairy Effluent, Bacillus sp., Neutral Protease, Milk Agar, Mineral Salt Medium

\section{Introduction}

Food grade proteases are proteyolytic enzymes having application in baking, food processing, protein modification etc. As a commodity product, pressure on protease market is on prize reduction and increasing performance. Industrial production of enzymes dates back to 1894 when 'fungal takadiastase' was marketed for pharmaceutical use (Singh 1998). Enzymes have been produced commercially from plants, animals, and microbial source. However, microbial enzymes have the enormous advantage of being able to produce in large scale quantities by established fermentation techniques (Stanburg et al., 1995). At present, economically most important industrial enzymes are extracted from bacteria (Bacillus sp., Staphylococcus sp., (Pseudomonas sp.), fungi (Aspergillus sp., Candida sp., Saccharomyces sp.) and Actinomycetes (Streptomyces sp.). Over 300 tons of enzymes are being annually produced from Bacillus sp. and most of them are proteases (Kumar 1998). Solid as well as submerged fermentation has been widely used for the production of proteases (Pandy et al., 2000a, Dunaevsky et al., 2000).
Proteases are the single class of enzymes, which occupy a pivotal position with respect to their applications in both physiological and commercial fields. They are degradative enzymes, which catalyze the total hydrolysis of proteins. Advances in analytical techniques have demonstrated that proteases conduct highly specific and selective modifications of proteins such as activation of zymogenic forms of enzymes by limited proteolysis, blood clotting and lysis of fibrin clots, and processing and transport of secretary proteins across the membranes. The current estimated value of the worldwide sales of industrial enzymes is $\$ 1$ billion (Godfrey et al., 1996). Proteolytic enzymes are the most important industrial enzymes, representing worldwide sales of about $60 \%$ of the total enzyme market (Woods et al., 2001, Raju et al., 1994, Mclntyre et al., 2000) and the industrial enzymes, $75 \%$ are of hydrolytic in nature.

The neutral proteases, which are active at neutral or weakly alkaline or weakly acidic $\mathrm{pH}$ include cysteine proteases, metalloproteases and some of the serine proteases. Thermolysin, a neutral protease, is the most thoroughly characterized member of metalloproteinase protease produced by Bacillus sp. Histidine residues from the 
HEXXH motif serve as Zn ligands and Glu has a catalytic function (Weaver et al., 1977). Thermolysin produced by $B$. stearothermophilus is a single peptide without disulfide bridges and has a molecular mass of $34 \mathrm{kDa}$. It contains an essential $\mathrm{Zn}$ atom embedded in a cleft formed between two folded lobes of the protein and four $\mathrm{Ca}$ atoms, which impart thermo stability to the protein. Thermolysin is a very stable protease, with a half-life of $1 \mathrm{~h}$ at $80^{\circ} \mathrm{C}$. Elastase produced by Pseudomonas aeruginosa is another important member of the neutral metalloprotease family. Recent studies showed that Bacillus species isolated from dairy effluent are used for the production of protease (T. M. Vijayalekshmi et al., 2015).

Dairy industry waste water contain large amount of organic and inorganic substances organic matter fat, protein and carbohydrates and nutrients mainly nitrogen and phosphorus origination from the milk and the milk products. Micro organisms are considered potentially to be the most suitable sources of neutral protease for industrial application. Among the various bacteria Bacillus sp. was found to be the major group producing protease (Ferrero et al., 1996). Hence the present study also deals with the isolation of Protease producing Bacillus sp. from the dairy industry plant effluent. The growth and enzyme production of the organism are strongly influenced by medium components like carbon and nitrogen sources. Besides the nutritional factors the cultural parameters like temperature, $\mathrm{pH}$, and incubation time were also plays a major role in enzyme production (Afshan et al., 2011, C. A, Mazzucotelli et al., 2014). The optimization of media components and cultural parameters are the primary task in a biological process. So, that media components and cultural conditions are optimized by providing different incubation condition. Hence our objective was to isolate a potent protease-producing microorganism and formulate a cost effective medium for neutral protease synthesis by the potent microbial culture.

\section{Materials}

\subsection{Sample Collection}

Soil samples were collected in a sterile polythene bag from kitchen premises near the institution and immediately transferred to the laboratory for the isolation of bacteria.

\subsection{Methods}

\subsubsection{Isolation of Protease Producing Bacteria}

The bacteriological studies were carried by serial dilutions followed by plating and later this culture was used for further studies based on their morphological and biochemical characteristics as out lined in the Bergey`s Manual of determinative bacteriology (Buchanan et al., 1972). 1gm of soil sample was mixed with $9 \mathrm{ml}$ of saline solution i.e. master dilution and $1 \mathrm{ml}$ of solution was serially transferred to tubes containing $9 \mathrm{ml}$ saline each so that for each transfer the suspension was diluted 10 times. Each tube was shaken vigoursly. $0.1 \mathrm{ml}$ solution was spread to petri plates containing milk agar medium ( $\mathrm{pH} \mathrm{7)}$ and incubated for $24 \mathrm{~h}$ at $37^{\circ} \mathrm{C}$.
Colonies showing proteolytic activity was selected and further purified. The milk agar medium contains $(\mathrm{g} / \mathrm{L})$ Skimmed milk powder 100, Peptone waste water 5, Agar $15 \mathrm{~g}$. Here milk powder was autoclaved separately.

\subsubsection{Submerged Fermentation for Enzyme Production}

The proteolytic bacteria was inoculated into $40 \mathrm{ml}$ seed culture media in a $250 \mathrm{ml}$ conical flask and kept in an environmental shaker at $120 \mathrm{rpm}$ and $37^{\circ} \mathrm{C}$ for $24 \mathrm{~h}$.

\subsubsection{The Composition of Seed Culture Medium (LB Media $\mathrm{PH}$ 7)}

Tryptone - $10 \mathrm{gm}$

Yeast extract - 5gm

Sodium chloride - 10gm

Distilled water - $1000 \mathrm{ml}$

$1 \mathrm{ml}$ of $24 \mathrm{~h}$ old seed culture was inoculated into $40 \mathrm{ml}$ of production media $(10,20,30,40,50$ and $100 \% \mathrm{~V} / \mathrm{V})$ in a $250 \mathrm{ml}$ of conical flask and incubated in an environmental shaker at $120 \mathrm{rpm}$ and $37^{\circ} \mathrm{C}$ for $48 \mathrm{~h}$. In this study, waste water from Dairy Industry supplemented with mineral salt was treated as production medium. Diary wastewater was collected in a sterile bottle from Manjor milks, Kottayam, Kerala.

The culture medium was then centrifuged at $4^{\circ} \mathrm{C}$ and $7500 \mathrm{rpm}$ for 15 minutes. The supernatant was collected in vials and estimated for neutral protease activity.

\subsubsection{Composition of Mineral Salt Medium}

$$
\begin{aligned}
& \text { Yeast extract - 1gm } \\
& \left.\mathrm{NH}_{4}\right)_{2} \mathrm{SO} 4-2 \mathrm{gm} \\
& \mathrm{K}_{2} \mathrm{HPO}_{4}-1 \mathrm{gm} \\
& \mathrm{KH}_{2} \mathrm{PO}_{4}-1 \mathrm{~g} \\
& \mathrm{MgSO}_{4} \cdot 7 \mathrm{H}_{2} \mathrm{O}-0.4 \mathrm{gm} \\
& \mathrm{MnSO}_{4} \cdot \mathrm{H}_{2} \mathrm{O}-0.01 \mathrm{gm} \\
& \mathrm{FeSO}_{4} \cdot 7 \mathrm{H}_{2} \mathrm{O}-0.1 \mathrm{gm} \\
& \text { Distilled water }-1000 \mathrm{ml}
\end{aligned}
$$

\subsubsection{Neutral Protease Assay}

Enzyme Assay involves estimation of amount of tyrosine released during the hydrolysis of protein. The Folins Ciocalteau reagent reacts with tyrosine released to produce a blue coloured complex (Lowry et al., 1951), which was read at $660 \mathrm{~nm}$.

\section{i. Reagents}

$0.2 \mathrm{M}$ Potassium phosphate buffer (1M), pH 7.5

Casein $(1 \%)$

TCA $(10 \%)$

$0.44 \mathrm{M} \mathrm{Na}_{2} \mathrm{CO}_{3}$

Folin's reagent $(1: 1)$

\section{ii. Procedure}

To $0.2 \mathrm{ml}$ of enzyme extract, $0.5 \mathrm{ml}$ of casein (1\%) and 0.3 $\mathrm{ml}$ of $0.2 \mathrm{M}$ phosphate buffer $\mathrm{pH} 7$ was added. The reaction mixture was then incubated at $60^{\circ} \mathrm{C}$ for 10 minutes and arrested by adding $1 \mathrm{ml}$ of $10 \%$ TCA. Then reaction mixture was then centrifuged at $3000 \mathrm{rpm}$ for 15 minutes and to the supernatant collected, $5 \mathrm{ml}$ of $0.44 \mathrm{M} \mathrm{Na}_{2} \mathrm{CO}_{3}$ and $1 \mathrm{ml}$ of 2 fold diluted folin Ciocalteau reagent was added. The 
resulting solution was then incubated for 30 minutes at $30^{\circ} \mathrm{C}$ and absorbance read at $660 \mathrm{~nm}$ (Keay et al., 1970). One unit of enzyme activity can be defined as the amount of enzyme that liberated $1 \mu \mathrm{g}$ of tyrosine $\mathrm{min}^{-1}$ under assay condition and reported in terms of unit per $\mathrm{ml}$.

\subsection{Identification of Proteolytic Bacteria Isolated from Soil}

The selected potential strain was then identified by morphological and biochemical characteristics by using microbiology laboratory manual.

\subsubsection{Morphological Characters}

The cell shape, pigmentation and fluorescence of the isolated bacteria were studied using microscope.

\subsubsection{Motility}

Hanging drop slides were prepared from nutrient broth cultures (18h old) were observed under microscope.

\subsubsection{Gram Staining}

Gram staining was done using smear preparations from 18 $\mathrm{h}$ old cultures. The slides were heat fixed and treated with crystal violet for 1 minute. Rinsed gently in a stream of water, dried, blotted and flooded with grams iodine solution for 1 minute. Washing in $95 \%$ alcohol for $30 \mathrm{sec}$ and rinsing in water followed this. After drying, slides were flooded with saffranin, a counter stain for 1 minute, again washed with gentle stream of water blotted to dryness and observed under oil immersion.

\subsubsection{Biochemical Tests}

\section{i. Carbohydrate Fermentation}

Four types of carbohydrates (glucose, fructose, lactose, sucrose) were used as substrate for fermentation test. Each carbohydrate was dissolved separately and $\mathrm{pH}$ was adjusted to 7 . Medium was sterilized at $15 \mathrm{lb}$ for 15 minutes. When cooled they were inoculated with the bacterial strain. A control was kept and the tubes were incubated at $37^{\circ} \mathrm{C}$ for 48 $\mathrm{h}$ and the biochemical changes were observed.

\section{ii. Citrate Test}

The Simmons citrate agar medium was prepared, transferred to culture tubes and sterilized at $15 \mathrm{lb}$ for 15 minutes. The bacteria were streaked in the slants with sterile loop and incubated for $48 \mathrm{hrs}$ at $37^{\circ} \mathrm{C}$. Then the biochemical changes are observed.

\section{iii. Indole Test}

Tryptone broth was prepared in the test tubes and sterilized. The medium was incubated with a loop full of culture and incubated at $37^{\circ} \mathrm{C}$ for $48 \mathrm{~h}$. $0.3 \mathrm{ml}$ of Kovac's reagent was added to $5 \mathrm{ml}$ of broth culture. The tubes were shaken and as allowed to stand for 5 minutes. The observations were noted.

\section{iv. Methyl Red Test}

The glucose phosphate broth was sterilized, was inoculated with bacterial culture and incubated at room temperature for
48 h. A few drops of methyl red indicator were added and observations were noted.

\section{v. Voges - Proskauer Test.}

The tubes of glucose phosphate broth were inoculated with a loop full of bacterial cultures. The tubes were then incubated at room temperature for $48 \mathrm{hrs}$. Then $3 \mathrm{ml}$ of $40 \%$ $\mathrm{KOH}$ solution was added. The observation was then noted.

\section{vi. Catalase Test}

A few drop of $\mathrm{H}_{2} \mathrm{O}_{2}$ was kept on a clean glass slide. A loop full of isolated bacterial culture was placed into the drop and the observations were noted.

\section{vii. $\mathrm{H}_{2} \mathrm{~S}$ Production}

This test is used to differentiate the ability of the microorganism to produce hydrogen sulphide gas from substrate such as sulphur containing amino acid or inorganic sulphur complex. The bacteria was streaked on a SIM agar media and incubated at $37^{\circ} \mathrm{C}$ for $48 \mathrm{~h}$. The observations were noted after $48 \mathrm{~h}$.

\section{viii. Urease Test}

Inoculate loop full of bacteria into a tube containing urea broth and streak on a urea agar. Incubate the tubes and plates at $37^{\circ} \mathrm{C}$ for $48 \mathrm{~h}$. The observations were noted.

\subsection{Maintenance of the Microorganisms}

The microorganisms were maintained on nutrient agar slant and incubated for $24 \mathrm{hrs}$ at $37^{\circ} \mathrm{C}$. The slants were stored at $4^{\circ} \mathrm{C}$ in refrigerator and sub cultured regularly at every 2 week interval.

\subsection{Growth of Potent Culture in Seed Culture Medium}

The growth of the potent culture was determined by measuring the turbidity of the seed culture medium at $660 \mathrm{~nm}$ at an interval of $2 \mathrm{~h}$ up to $30 \mathrm{~h}$.

\subsection{Effect of Mineral Salt Supplementation in Dairy Industry Wastewater for Protease Production}

The efficiency of mineral salt supplementation in dairy wastewater was studied by comparing neutral protease production in both wastewater medium and also mineral salt supplemented wastewater medium. Both the medium was then inoculated with the potent culture and incubated at $37^{\circ} \mathrm{C}$ and $120 \mathrm{rpm}$ for $48 \mathrm{~h}$.

\subsection{Effect of PH on Protease Production}

The medium $\mathrm{pH}$ was adjusted using $0.1 \mathrm{~N} \mathrm{HCl}$ or $0.1 \mathrm{~N}$ $\mathrm{NaOH}$. The influence of medium $\mathrm{pH}$ was studied at 4, 5, 6, 7, 8, and 9 . The experiment was conducted in waste water medium.

\section{Result and Discussion}

\subsection{Isolation of Proteolytic Bacteria}

Table 1 showed the zone of hydrolysis produced by the 
proteolytic bacteria. 9 proteolytic bacterial colonies were obtained in milk agar medium. Bacterial culture Sample 3 (S3) showed maximum hydrolytic zone (diameter $10 \mathrm{~mm}$ ) was selected for further study. Figure 1 proteolytic activity observed with the potent culture on milk agar. Usually a plate assay on milk agar medium will be carried out to isolate protease-producing organisms by measuring the clear zone of hydrolysis formed on milk agar (Ellaiah et al., 2002, Rajamani et al., 1987, Adesh et al., 2002).

Table 1. Zone of hydrolysis by proteolytic bacteria.

\begin{tabular}{ll}
\hline Bacterial cultures & Zone of hydrolysis (mm) \\
\hline S1 & 0 \\
S2 & 9 \\
S3 & 10 \\
S4 & 7 \\
S5 & 6 \\
S6 & 5 \\
S7 & 5 \\
S8 & 6 \\
S9 & 8 \\
\hline
\end{tabular}

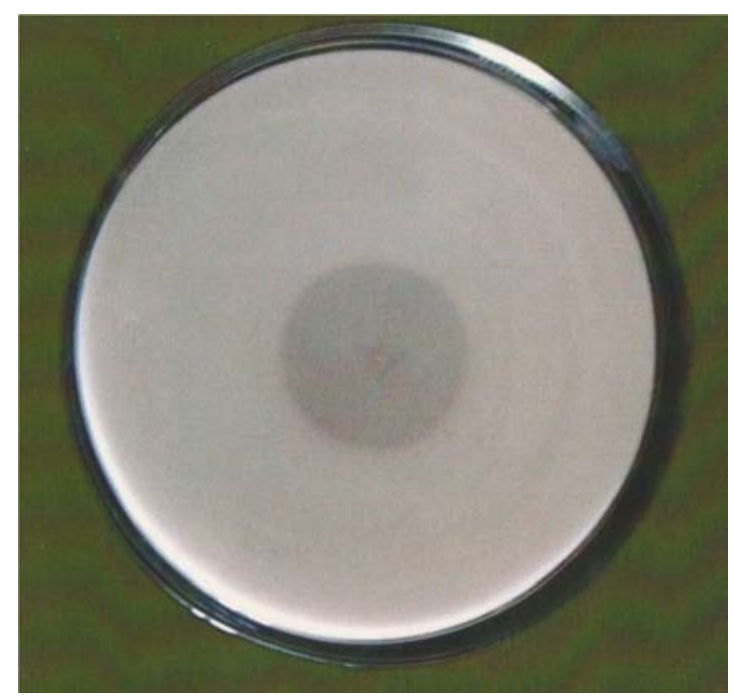

Figure 1. Zone of hydrolysis

\subsubsection{Production of Neutral Protease by Submerged Fermentation}

Synthesis and secretion of extra cellular proteases by microorganisms was reported to be influenced by inducers and its concentration in the medium. Casein was used as an inducer for protease synthesis by Aspergillus sp (Nehara et al., 2004). The potent proteolytic bacterium obtained was then studied for neutral protease production by submerged fermentation. The potent culture was then inoculated into different concentrations of production medium and incubated for $48 \mathrm{~h}$ at $37^{\circ} \mathrm{C}$ and $120 \mathrm{rpm}$. The effect of different concentrations of the medium on neutral protease synthesis is presented in figure 2. Optimum neutral protease synthesis was observed with $100 \%$ medium. Figure $3, \mathrm{~A}, \mathrm{~B}$, and $\mathrm{C}$ were showed different stages of protein synthesis, Aproduction of crude enzyme, $\mathrm{B}$ - control dairy effluent alone $\mathrm{C}$ - purified enzyme by centrifugation respectively. Casein content in the waste water might be the inducer. This shows that mineral salt supplemented waste medium is an effective neutral protease producing medium.

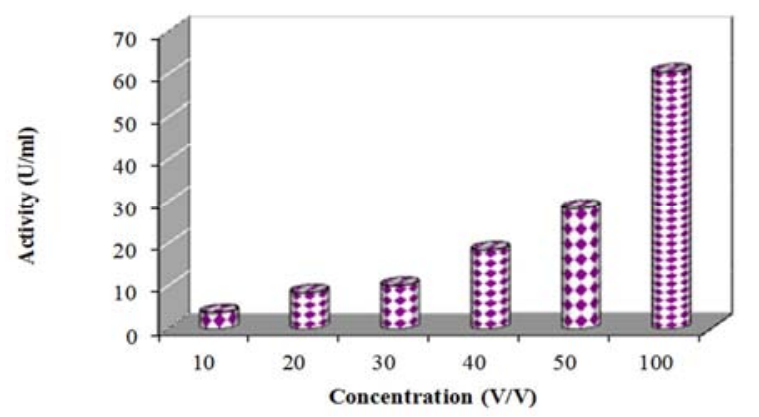

Figure 2. Effect of different medium concentrations on neutral protease synthesis.

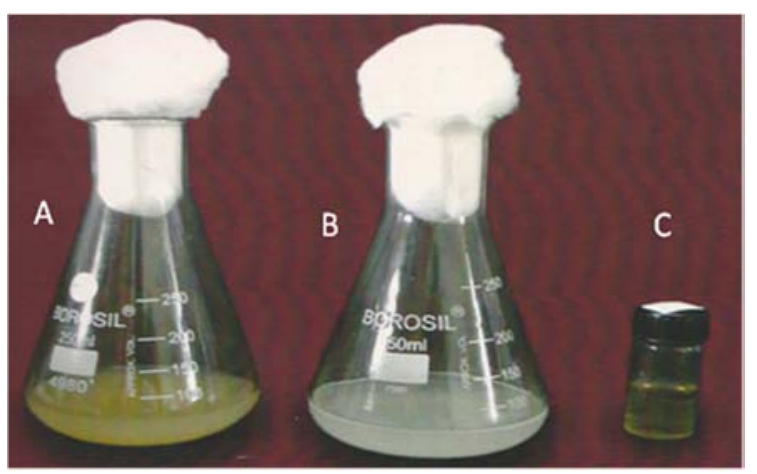

Figure 3. (a) After production, (b) Control (c) Purified enzyme

\subsubsection{Identification of Proteolytic Bacteria}

The result of the study is depicted in table 2 .

Table 2. Biochemical characterization of bacteria.

\begin{tabular}{ll}
\hline Morphological characters & \\
\hline Motility & Motile \\
Shape & Rod \\
Gram staining & + ve \\
Pigmentation & - \\
Florescence & - \\
Biochemical characters Carbohydrate Fermentation \\
Lactose & - ve \\
Glucose & - ve \\
Fructose & - ve \\
Sucrose & - ve \\
Mannitol & - ve \\
IMVIC TEST & \\
Indole & - ve \\
Methyl red & - ve \\
Vogues proskauer & - ve \\
Citrate utilization & - ve \\
Catalase & + ve \\
H 2 S production & - ve \\
Urease test & - ve \\
\hline
\end{tabular}

Experiments on morphological characters of the selected bacterial strain (S3) showed it was a Gram positive, rod shaped, motile organism. The organism was identified as Bacillus cereus by biochemical characterization. Maintenance of the potent culture on nutrient agar slants is shown in the figure 4 . 


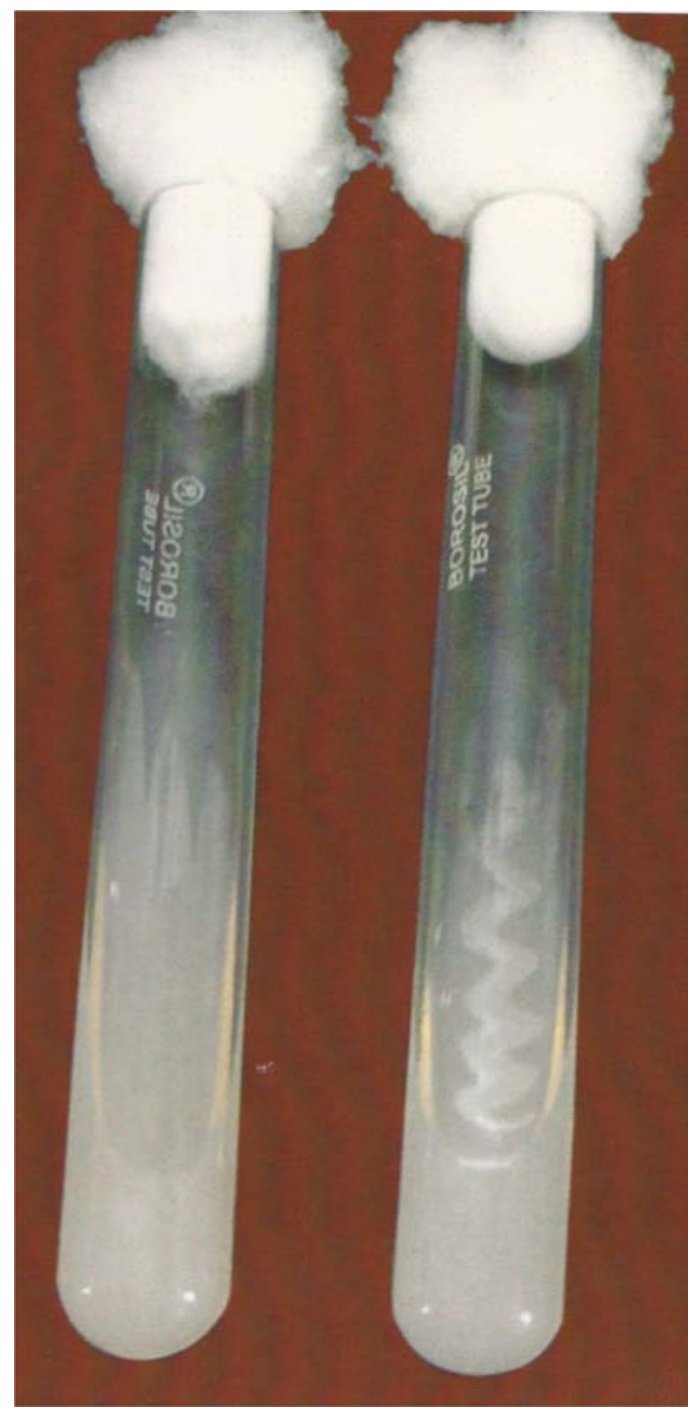

Figure 4. Stock Culture in agar slant.

\subsubsection{Growth of Potent Culture in Seed Culture Medium}

The growth of the potent culture was determined by measuring turbidity of the medium at an interval of $2 \mathrm{~h}$. Figure 5 depicts the growth curve of the organism. $26 \mathrm{~h}$ old culture showing exponential growth was selected for further study.

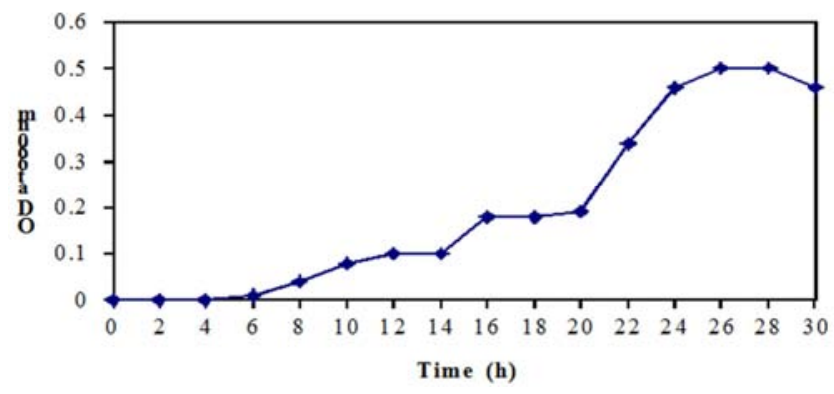

Figure 5. Growth curve of the potent bacteria

\subsubsection{Comparison of Neutral Protease Synthesis in Mineral Salt Enriched Wastewater Medium and Waste Water}

A comparative study on neutral protease production in both waste water and mineral enriched waste water medium showed increases the titers with waste water medium. The result of the study is given in figure 6. This showed that Dairy Industry waste water alone can be an effective medium for neutral protease production.

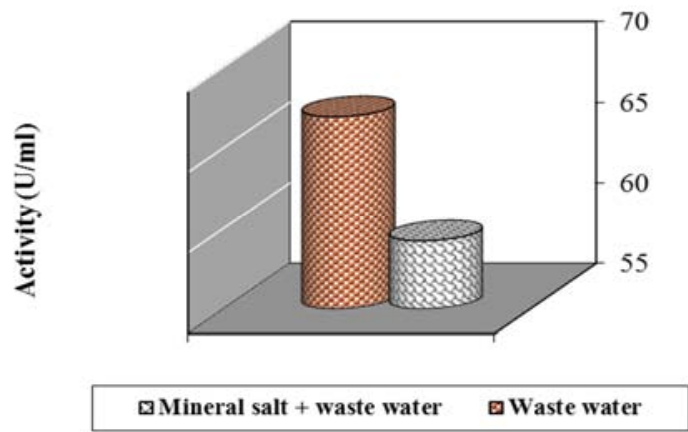

Figure 6. Comparison of mineral salt supplemented and waste water medium.

\subsubsection{Effect of Medium PH on Neutral Protease Production}

The study was carried out by changing medium $\mathrm{pH}$. The result obtained is as shown in figure 7 . From the result, it was clear that optimum neutral protease synthesis is at $\mathrm{pH}$ 7. The culture $\mathrm{pH}$ was reported to strongly affect many enzymatic processes and transport of various components across the cell membrane (Moon et al., 1991). Protease production was maximum when Bacillus horikoshii was grown in a medium of $\mathrm{pH} 9$ while 6.5-7.5 was reported optimum $\mathrm{pH}$ for neutral protease production by $P$. fluorescens and B. megaterium.

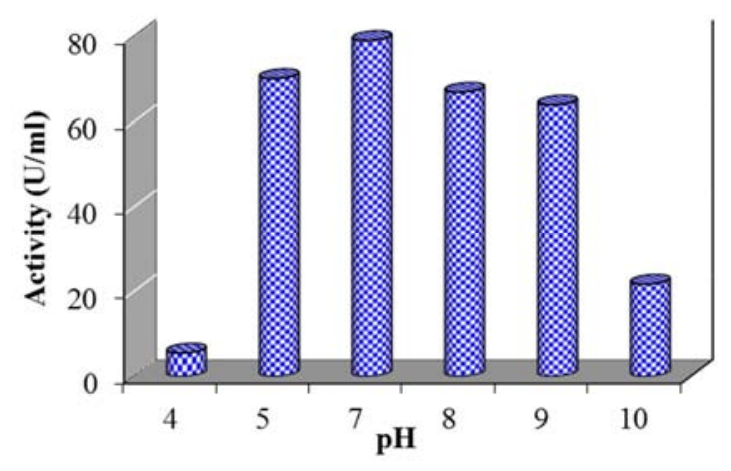

Figure 7. Effect of medium $\mathrm{pH}$ on neutral protease synthesis.

\section{Conclusion}

In the present study, a potent proteolytic bacteria was isolated from soil sample using milk agar medium. Dairy industry wastewater was found to be an effective production medium for neutral protease synthesis. The potent organism was identified as Bacillus cereus by morphological and biochemical characterization. A comparative study on effect of mineral salt supplemented wastewater and wastewater without mineral salt showed increased production with waste water medium. Medium $\mathrm{pH}$ was found to have a profound influence on neutral protease production by the potent organism. The optimum $\mathrm{pH}$ was found to be 7 . From the 
results it can be concluded that $B$. cereus is a potent bacteria and Dairy Industry waste water an effective medium for neutral protease synthesis. Detailed study require for the large scale production food grade protease.

\section{References}

[1] Singh. B. D (1998) Introduction to Biotechnology, Industrial biotechnology Kalyani Publications New Delhi p 1-11.

[2] Stanburg. P. F., Whitaker, A and Hall, S. J. (1995) Principal of Fermentation Techniques: Introduction of fermentation process $2^{\text {nd }}$ ed. p. 2.

[3] Kumar. H. D. (1998) a textbook of biotechnology, Affiliated East - West press private limited New Delhi India p. 173.

[4] Panday. A and Scool. C. R. (2000a) Economic utilization of crop residues for value addition - A futuristic approach, Journal of Scientific and Industrial research 59, 12-22.

[5] Dunaevsky. Y E., Grubun T. N., Beliakova. G. A., Belozersky. M. A. (2000) Protease secreted by filamentous fungi Trichoderma harzanum Biochemistry (Moscow) 65, 723-727.

[6] Godfrey. T and West. S. (1996) Industrial enzymology $2^{\text {nd }} \mathrm{Ed}$, New York, N. Y. Macmillan Publishers Inc. p. 3.

[7] Woods. R., Burger. M., Bevan. C and Beacham. I, (2001) Extracellular enzyme Production in Pesudomonas flurescene Journal of Microbiology, 143 345-354.

[8] Raju. K., Jaya. R. and Ayyanna. C., (1994) Hydrolysis of casein by bajara protease importance, Biotechnol. Coming Decades 181, 55-70.

[9] Mclntyre. M., Berry, D. R. and NcNeil. B., (2000), Role of protease in autolysis of Pencillium chrysogenum, Applied Microbiology and Biotechnology, 53, 235-242.

[10] Weaver. L. H., Kester. W. R and Matthews. B. W. (1977), A crystallographic study of the complex of phosphoramidon with thermolysin, A model for the presumed catalytic translation state and for the binding of structures, Journal of Molecular Biology 114, 119-132.

[11] T. M. Vijayalakshmi, R. Murali (2015), Isolation and screening of Bacillus subtilius isolated from the dairy effluent for the production of protease. International Journal of Current Microbiology and Applied Science pp. 820-827.

[12] C. A. Mazzucotelli, I. Durruty, C. E. Kotlar, M, R. Moreira, A. G. Ponce, S. I. Roura (2014), Develpoment of a microbial consortium for dairy waste water treatment. Biotechnology and Bioprocess engineering Volume 19, Issue 2, pp. 221-230.

[13] Ferrero M. A., Castro G. R., C. M. Abate C. M., Baigori. M. D., Sineriz. F. Appl. Microbiol. Biotechnol., 1996, 45, 327332 .

[14] Afshan Jameel and Mazharuddin Khan Mohd, (2011), International Journal of Engineering Science and Technology, 4596-4603.

[15] Buchanan. R. G and Gibbons. N. E. (1975) Bergey's Manual of Determinative Bacteriology $8^{\text {th }}$ ed., Williams and Wikins Baltimore.

[16] Lowry. O. H., Rosbrugh. N. J., Farr. A. L and Randall. R. J. (1951) protein measurement with Folins phenol reagent Journal of biological Chemistry 193, 265-275.

[17] Keay. L and Wildi. B. S. (1970), Protease of genus Bacillus I, Neutral protease Biotechnology, Biogeng. XII, 179-212.

[18] Ellaiah, P., Adinarayana. K., Pardhasaradhi. S. V and Srinivaulu. B. (2002), Isolation alkaline protease producing bacteria from Vishakapattanam soil, Indian Journal of Microbiology 42, 173-175.

[19] Rajamani. S and Hilda. A. (1987), Plate assay to screen fungi for proteolytic activity, Current Science, 56, 22. 1179-1181.

[20] Adesh. K., Archana. S. Balasubryamanyan, Sexena. A. K and Lata. (2002), Optimization condition for production of neutral and alkaline protease from species of Bacillus and Pseudomonas Indian Journal of Microbiology, 42: 233-236.

[21] Nehra. K S., Singh K. S., Sharma. J., Kumar. R and Dhillon. S, (2004), Production and characterization of alkaline protease from Aspergillus sp. and its compatibility with commercial detergents. Asian Journal of Microbiology biotechnology and Environmental Science, 6: 1, 67-72.

[22] Moon. S. H, Parulekar. S. J. (1991) A parametric study ot protease production in batch and fed-batch cultures of Bacillus firmus Biotechnol Bioeng 5; 37 (5): 467-83. 